\title{
Behavioral response of Panonychus citri (McGregor) (Acari: Tetranychidae) to synthetic chemicals and oils
}

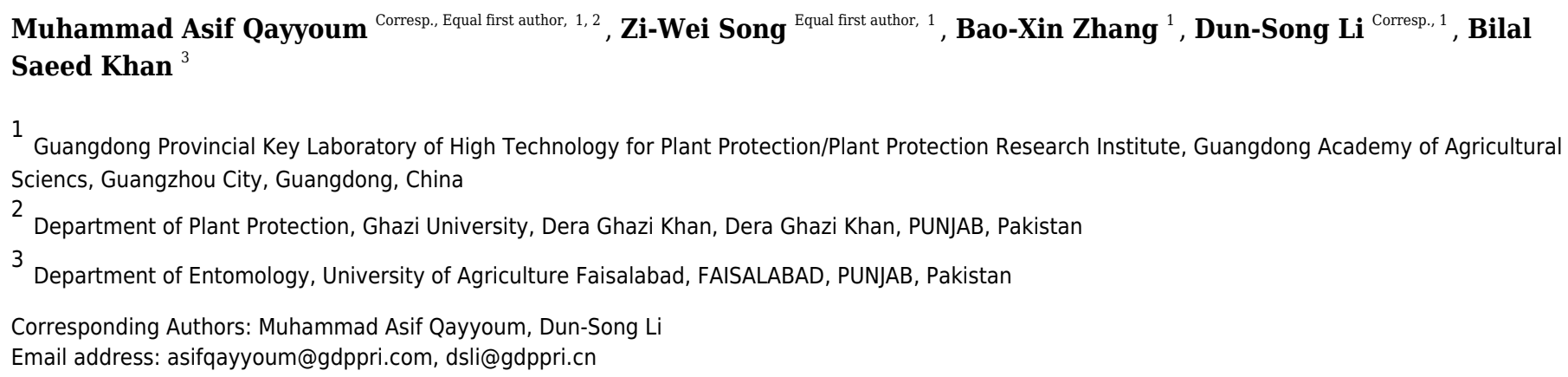

Background Panonychus citri (McGregor) (Acari: Tetranychidae) population outbreaks after the citrus plantation's chemical application is a common observation. Dispersal behavior is an essential tool to understand the secondary outbreak of $P$. citri population. Therefore, in the current study, the dispersal activity of $P$. citri was observed on the leaf surfaces of Citrus reticulata (Rutaceae) treated with SYP-9625, abamectin, vegetable oil, and EnSpray 99. Method Mites were released on the first (apex) leaf of the plant (adaxial surface) and data were recorded after $24 \mathrm{~h}$. The treated, untreated, and half-treated data were analyzed by combining the leaf surfaces (adaxial right, adaxial left, abaxial right, and abaxial left). All experiments were performed in open-air environmental conditions. Results The maximum number of mites was captured on the un-treated or half-treated surfaces due to chemicals repellency. Chemical bioassays of the free-choice test showed that all treatments significantly increased the mortality of $P$. citri depending on application method and concentration. A significant number of mites repelled away from treated surfaces and within treated surfaces except adaxial left and abaxial right surfaces at $\mathrm{LC}_{30}$. In the nochoice test, SYP-9625 gave maximum mortality and dispersal by oils than others. No significant differences were observed within the adaxial and abaxial except abaxial surface at $\mathrm{LC}_{30}$. Therefore, the presence of tested acaricides interferes with $P$. citri dispersal within leaf surfaces of plantations depending on the mites released point and a preferred site for feeding. 
1 Behavioral response of Panonychus citri (McGregor)

2 (Acari: Tetranychidae) to synthetic chemicals and oils

3

4

5

7

\begin{abstract}
Muhammad Asif Qayyoum ${ }^{1,2}$, Zi-Wei Song ${ }^{1 *}$, Bao-Xin Zhang ${ }^{1}$, Dun-Song Li $^{1 *}$, Bilal Saeed
\end{abstract} $\mathrm{Khan}^{3}$

${ }^{1}$ Guangdong Provincial Key Laboratory of High Technology for Plant Protection/Plant Protection Research Institute, Guangdong Academy of Agricultural Sciences, 7 Jinying Road, Tianhe District, Guangzhou 510640, China.

${ }^{2}$ Department of Plant Protection, Ghazi University, Dera Ghazi Khan, Punjab province, Pakistan.

${ }^{3}$ Department of Entomology, University of Agriculture, Faisalabad, Punjab province, Pakistan. Corresponding Authors:

Zi-Wei Song, Dun-Song Li, Muhammad Asif Qayyoum

Guangdong Provincial Key Laboratory of High Technology for Plant Protection/Plant Protection Research Institute, Guangdong Academy of Agricultural Sciences, 7 Jinying Road, Tianhe District, Guangzhou 510640, China.

Email address: asifqayyoum@gmail.com/asifqayyoum@gdppri.com; ziweisong@139.com; dsli@gdppri.cn

\title{
Abstract
}

\section{Background}

Panonychus citri (McGregor) (Acari: Tetranychidae) population outbreaks after the citrus plantation's chemical application is a common observation. Dispersal behavior is an essential tool to understand the secondary outbreak of $P$. citri population. Therefore, in the current study, the dispersal activity of $P$. citri was observed on the leaf surfaces of Citrus reticulata (Rutaceae) treated with SYP-9625, abamectin, vegetable oil, and EnSpray 99.

Method

Mites were released on the first (apex) leaf of the plant (adaxial surface) and data were recorded after $24 \mathrm{~h}$. The treated, untreated, and half-treated data were analyzed by combining the leaf surfaces (adaxial right, adaxial left, abaxial right, and abaxial left). All experiments were performed in open-air environmental conditions.

Results

The maximum number of mites was captured on the un-treated or half-treated surfaces due to chemicals repellency. Chemical bioassays of the free-choice test showed that all treatments significantly increased the mortality of $P$. citri depending on application method and concentration. A significant number of mites repelled away from treated surfaces and within 
40 treated surfaces except adaxial left and abaxial right surfaces at $\mathrm{LC}_{30}$. In the no-choice test, 41 SYP-9625 gave maximum mortality and dispersal by oils than others. No significant differences 42 were observed within the adaxial and abaxial except abaxial surface at $\mathrm{LC}_{30}$. Therefore, the 43 presence of tested acaricides interferes with $P$. citri dispersal within leaf surfaces of plantations 44 depending on the mites released point and a preferred site for feeding.

45

\section{Introduction}

47

48

49

50

51

52

53

54

55

56

57

58

59

60

61

62

63

64

65

66

67

68

69

70

71

72

73

74

75

76

77

78

The citrus red mite, Panonychus citri, is a serious pest of the citrus growing region all over the world (Gotoh \& Kubota, 1997; Kasap, 2009; Faez et al., 2018b; Korhayli et al., 2018) as well as in China (Yuan et al., 2010; Fang et al., 2013; Liu et al., 2019). The immature and adult stages feed on leaves and fruit by giving stippling damage, which inhibits the photosynthesis process and leads shoot dieback and leaf/fruit dropping (Kranz et al., 1978). Server infestation in the field may cause irritation and allergic reactions to citrus workers (Fernández-Caldas et al., 2014). The chemicals application is a preferred method to control $P$. citri by the farmers in citrus orchards (Gotoh \& Kubota, 1997; Chen et al., 2009; Kasap, 2009; Fadamiro et al., 2013; Faez et al., 2018a,b; Karmakar, 2019; Liu et al., 2019). SYP-9625 and abamectin are commonly used among synthetic chemicals against citrus pests in China (Gu et al., 2010; Hu et al., 2010; Liu et al., 2018; Chen et al., 2019). It is essential to find alternative products (Isman, 2008; Tak \& Isman, 2017) for synthetic chemicals due to serious threats to non-target organisms and the environment (Kumral et al., 2010; Chen \& Dai, 2015). Agricultural mineral oils (EnSpray 99) are compatible with predatory mites application and effective against horticultural crop pests (Wang et al., 2004; Chen \& Zhan, 2007; Xue et al., 2009a,b; Teifemg et al., 2011; Zhuang et al., 2015). Vegetable oils are also considered an alternative due to toxicity and repellency against target pests (Koulbanis et al., 1984; Ismail et al., 2011; Oliveira et al., 2017). Vegetable oil extracted from kitchen/household waste (vegetable remaining) were used in this study. Guangdong Institute of Applied Biological Resources, China, provided this kitchen vegetable waste oil (as a trial product).

Environmental contamination such as pesticides can influence mites behavioral activities on leaves or plants (Ibrahim \& Yee, 2009; Lima et al., 2013; Cordeiro et al., 2014; Monteiro et al., 2019a). The behavioral changes due to chemicals affect pest management strategies (Guedes et al., 2016). The population outbreaks of plant-feeding mites after the chemical application on the horticultural crops are very common (AIiNiazee \& Cranham, 1980; Zwick \& Field, 1987). The abrupt increase of the mites population has many suggestions by the researchers; the most critical explanation suggests the impact of chemicals on the natural enemies (AIiNiazee \& Cranham, 1980; Dittrich et al., 1980; Zwick \& Field, 1987). Iftner \& Hall (1983) reported that increasing the chemical application rates in the absence of natural enemies also increases pest numbers. Since, the impact of agrochemicals on target pest or insect can be assessed through the application rate (lethal and sublethal), application timing, and mode of action. The use of the sublethal effect of chemicals is considered a more accurate approach to measure toxicity, which 
79 changes individuals behavioral responses that survive from toxic exposure (Desneux et al., 2007;

80 Biondi et al., 2013; Turchen et al., 2016; Alves et al., 2018).

81 Dispersal behaviors define as any movement from one place to another for the survival of any

82 organism due to environmental stress or non-viable to live (e.g., lack of food or surrounding 83 climatic constraints) (Clobert et al., 2001; Ims \& Hjermann, 2001). Dispersal movement done in 84 three stages; emigration, a vagrant stage, and immigration (Ronce, 2007), which depend on the 85 species life cycle, sex, environmental variations, space, and time (Dunning Jr et al., 1995; 86 Hanski, 1998, 1999; Turchin, 1998; Bergman et al., 2000; Bowler \& Benton, 2005).

87 The dispersal behavior of mites uses active or passive dispersal mechanisms (Evans, 1992; 88 Sabelis \& Afman, 1994; Tixier et al., 1998; Perotti \& Braig, 2009). Active dispersal (walking) is 89 the most preferred mechanism in mites due to morphological characteristics and short-range 90 travel (Strong et al., 1999; Melo et al., 2014; Monteiro et al., 2019a). Like most of the tetranychids, Panonychus citri also do passive dispersal by silk threads (aerial dispersal) to overcome crowding, food depletion (Bell et al., 2005), and light-dependent (Pralavorio et al., 1989). In this study, we evaluated the lethal and sublethal effects of selected pesticides on the dispersal pattern of $P$. citri by treating the leaf surfaces. We hypothesized that $P$. citri response towards chemicals treatment may be a reason for the population outbreak in the field conditions.

\section{Materials \& Methods}

\section{Mite Culture}

Mite culture was regularly maintained since 2019, on lemon leaves with the water-saturated sponge. The culture was reared in the growth chamber with a 16:8h (Light: Dark) photoperiod and $26 \pm 1{ }^{\circ} \mathrm{C}$ temperature. One to three-day-old adult females (He et al., 2011; Alves et al., 2018) were used for said experimentation reared in the laboratory for several generations (more than 50 generations). The one to three-day-old adult females were used due to fully developed adultery and ready for egg-laying after 4 to 5 days. The mite culture was shifted to the open-air environment one month before the experiment to acclimatize.

Plants

Citrus plants (Citrus reticulata) approximately 1-2 months old were used after shifting to the pots. The plants with 7 to 8 leaves were used by leaving six leaves ( 3 on the right and left side) and cutting them. All plants were washed three times with water to be sure not to have any arthropods on them. The bottom of each plant stem was wrapped with wet tissue paper and maintained wet to keep mites on the plant. All plants were manured and watered accordingly under reasonable conditions during January.

\section{Chemicals}

SYP-9625 30\% EC and Abamectin 5\%EC, EnSpray 99\% EC (EnSpray 99), and vegetable oil 99\% were used in this research. Chemicals and EnSpray were bought from the local market. The degummed vegetable oil was extracted from household daily kitchen vegetable waste that was provided by the Institute of Zoology, Guangdong Academy of Sciences.

Each chemical toxicity was calculated using a modified leaf dip bioassay (Wang et al., 1971; Nauen, 2005) previously in the laboratory. The selection concentrations of each chemical were 
119

120

121

122

123

124

125

126

127

128

129

130

131

132

133

134

135

136

137

138

139

140

141

142

143

144

145

146

147

148

149

150

151

152

153

154

155

made with $10 \%$ to $90 \%$ corrected mortality after $24 \mathrm{~h}$. Lethal and sublethal concentrations of each chemical were calculated by probit analysis using SPSS version 22.0 software (Weinberg \& Abramowitz, 2016). In this experiment, we used $\mathrm{LC}_{30}(0.065 \%, 0.049 \%, 0.024 \%$ and $0.08 \%)$ and $\mathrm{LC}_{50}(0.196 \%, 0.110 \%, 0.051 \%$ and $0.024 \%)$ for SYP-9625, Abamectin, Vegetable oil and EnSpray 99, respectively.

\section{Experimental methodology}

The method adopted by Iftner and Hall (1983) was followed for the current experiment. Letters were assigned to leaves surfaces as; adaxial right (ADR), adaxial left (ADL), abaxial right (ABR), and abaxial left (ABL). We used a free choice and no choice method by dividing it into nine small experiments, as shown in Fig. 1. Chemicals were applied to the treated leaf surface with a hand sprayer. Untreated part of leaflet or surfaces was protected from chemicals spraying by cardboard shield and plastic bags. Each plant's ground surface was covered with plastic with double side sticky tape on the edge. The right adaxial surface was selected for easy to release mites (20 mites x 3 surfaces) and identified mites location from the inoculated surface after 30 minutes of chemicals application. Mites were captured 24 hours by location as per the experimental layout. The mites on the leaf surface, wet tissue paper (chemically treated), and plastic cover (chemical sprayed) were considered as dead. The mites not found as live or dead were considered missing mites. The experiments were used with three replications.

The treated, un-treated, and half-treated data were combined for leaf surfaces (ADR, ADL, $\mathrm{ABAR}$, and $\mathrm{ABL}$ ) further analysis. All experiments were performed in open-air environmental conditions.

\section{Statistical analysis}

The mean number of mites $\left(\mathrm{LC}_{30}\right.$ vs $\mathrm{LC}_{50}$, Treated vs Un-treated, Treated vs Half-treated, and Adaxial vs Abaxial) were analyzed using an independent sample t-test. The difference between control and treatments captured mites means were analyzed using the general linear model (GLM) for ANOVA with Tukey's HSD test $(P<0.05)$. All statistical analysis procedures were calculated with Minitab ${ }^{\circledR}$ 17.3.1 version (Minitab, 2016). Graphical representation was done using GraphPad prism ${ }^{\circledR}$ (Motulsky, 2007) and OriginPro (Edwards, 2002).

A correlation analysis was conducted by comparing toxicity (\% mortality) and \% mites present on treated, un-treated, and half-treated surfaces to better understand the relationship between the behavioral responses of $P$. citri. Pearson correlation $(r)$ and calculating $t$ distribution value formulas were used in $\mathrm{R}$.

$$
\begin{gathered}
r=\frac{\sum(x-m x)(y-m y)}{\sqrt{\sum(x-m x)^{2} \sum(y-m y)^{2}}} \\
t=\frac{r}{\sqrt{1-r^{2}}} \sqrt{n-2}
\end{gathered}
$$

$\boldsymbol{n}$ is the length of factor $(d f=\mathrm{n}-2)$ in two vectors ( $\boldsymbol{x}$ (toxicity) and $\boldsymbol{y}$ (mites observed on treated or untreated or half treated surfaces) while $\boldsymbol{m} \boldsymbol{x}$ and $\boldsymbol{m y}$ are the means of vectors. The significant level can be determined by the $t$-value. 


\section{Results}

157 Toxicity

158 Compared to control, acute toxicity of treatments was found significantly different within each 159 dose in all experiments except in exp. no. 8 at $\mathrm{LC}_{30}$. There was significant difference between 160 doses within abamectin (For exp. no. $3 ; t_{-5.56}=-5.00 ; P=0.007$ ), SYP-9625 (For exp. no. $4 ; t_{-7.78}=-$ $1613.50 ; P=0.025$ ) and EnSpray (For exp. no. $4 ; t_{-8.89}=-8 ; P=0.001$, For exp. no. $6 ; t_{-6.67}=-3.464 ; P=$ 1620.026 ) and vegetable oil (For exp. no. $8 ; t_{-4.44}=-2.828 ; P=0.047$ ) than others. Differences in 163 toxicity (from $\mathrm{LC}_{30}$ to $\mathrm{LC}_{50}$ ) of chemicals to adult (female) $P$. citri occurred among experiments 164 depending on application methods, with ranges in SYP-9625, abamectin, vegetable oil, and 165 EnSpray of 1.156 - 2.399-fold, $1.33-5.556$ fold, $1.249-5.005$ fold and $0-8.889$ fold, 166 respectively. Maximum toxicity (\%) was observed in the no-choice experiment (the whole plant treated - exp. no. 9), and SYP-9625 more toxic (except in exp. no. 2) than others in all experiments (Table 1).

169

\section{Re-captured Panonychus citri}

171

172

173

174

175

176

177

178

179

180

181

182

183

184

185

186

187

188

189

190

191

192

193

194

195

According to Fig. 1, the experimental layout is further divided into three parts; Treated vs Untreated (Experiments 1-6), Treated vs Half-treated (Experiments 7-8), and the whole plant treated (Adaxial vs Abaxial) (Experiment 9).

Mites dispersal within the ADR surface were observed $40 \%$ to $82.24 \%\left(\mathrm{LC}_{30}\right)$ and 53.7 to 94.067\% $\left(\mathrm{LC}_{50}\right)$ from treated to untreated. The difference between treated and untreated was significantly recognizable. A significant difference was observed in all treatments between the mean number of mites captured on the treated and un-treated on the ADR: SYP-9625 $\left(t_{-9.22}=\right.$ $5.56 ; P=0.000)$, Abamectin $\left(t_{-7.667}=-8.37 ; P=0.000\right)$, vegetable oil $\left(t_{-10.78}=-9.17 ; P=0.000\right)$ and EnSpray $99\left(t_{-8.11}=-5.78 ; P=0.000\right)$ except control $\left(t_{-8.11}=-5.78 ; P=0.097\right)$, at $\mathrm{LC}_{30}$ while similar results found by applying the $\mathrm{LC}_{50}$ doses. The number of mites captured on the treated ADR surface was lower than the number of mites captured on the untreated surface. A maximum number of mites were observed under the un-treated $\mathrm{ADR}$ surface at $\mathrm{LC}_{30}$ dose of vegetable oil than in the others (Fig. 2).

On the Adaxial surface of left side (ADL), a significant difference was observed within all treatments between the mites captured on the treated and un-treated ADL surfaces: control $\left(t_{-2.778}\right.$ $=-2.94 ; P=0.015$ and $\left.t_{-2.778}=-2.94 ; P=0.015\right)$, SYP-9625 $\left(t_{-6}=-3.45 ; P=0.006\right.$ and $t_{-10.22}=-$ $8.72 ; P=0.000)$, Abamectin $\left(t_{-5.778}=-6.28 ; P=0.000\right.$ and $\left.t_{-7.78}=-5.29 ; P=0.001\right)$, vegetable oil $\left(t_{-4.22}=-2.37 ; P=0.042\right.$ and $\left.t_{-4.67}=-3.78 ; P=0.004\right)$ and EnSpray $99\left(t_{-4.33}=-3.99 ; P=0.002\right.$ and $\left.t_{-9.11}=-4.77 ; P=0.001\right)$ on the $\mathrm{LC}_{30}$ and $\mathrm{LC}_{50}$ doses respectively. A higher number of mites captured on the un-treated surface at $\mathrm{LC}_{50}$ of SYP-9625 than others (Fig. 3).

The Panonychus citri less visited the abaxial surface than the adaxial surface, so a small number of mites $(\mathrm{Mean} \pm \mathrm{SE})$ were captured but enough for the difference between treated and untreated surfaces. At $\mathrm{LC}_{30}$ doses, the data collected from abaxial surface of right side (ABR) was significantly different on treated and untreated surfaces: Abamectin $\left(t_{-1.889}=-6.8 ; P=0.000\right)$, EnSpray $99\left(t_{-1.889}=-3.3 ; P=0.005\right)$ and control $\left(t_{-1.444}=-2.25 ; P=0.041\right)$. By treating ABR 
196

197

198

199

200

201

202

203

204

205

206

207

208

209

210

211

212

213

214

215

216

217

218

219

220

221

222

223

224

225

226

227

228

229

230

231

232

233

234

235

with lethal concentrations $\left(\mathrm{LC}_{50}\right)$ was significantly different on treated and untreated surfaces by treated with vegetable oil $\left(t_{-3.222}=-4.24 ; P=0.002\right)$ while SYP-9625, abamectin, and EnSpray 99 were similar between the replication within treated or untreated. The number of mites found maximum on the un-treated $\mathrm{ABR}$ surface treated with $\mathrm{LC}_{50}$ of abamectin (6.78 \pm 0.813 ) (Fig. 4).

The difference between treated and un-treated was observed significant within all treatments: SYP-9625 $\left(t_{-2}=-4.1 ; P=0.003\right)$, abamectin $\left(t_{-3.11}=-4.37 ; P=0.002\right)$, vegetable oil $\left(t_{-2}=-4.94\right.$; $P=0.001)$ and EnSpray $99\left(t_{-2.33}=-3.61 ; P=0.006\right)$ except control at $\mathrm{LC}_{30}$ doses on the abaxial surface of left side (ABL). No mites were observed after treatment with $\mathrm{LC}_{50}$ doses on $\mathrm{ABL}$ except vegetable oil $\left(t_{-3.33}=-4.87 ; P=0.001\right)$ and control (non-significant). Maximum number of mites found on un-treated surfaces depending on the concentration of chemicals (Fig. 5).

On the adaxial surfaces, difference between treated and half-treated surfaces were found similar (non-significant) at $\mathrm{LC}_{30}$ except on vegetable oil application $\left(t_{4.33}=2.8, P=0.038\right)$ while at $\mathrm{LC}_{50}$, all treatments found significant different (For SYP-9625: $t_{8.5}=8.77, P=0.000$; abamectin: $t_{9.167}$ $=10.51, P=0.000$; vegetable oil: $t_{6.167}=9.43, P=0.000$; EnSpray: $t_{8.5}=7.54, P=0.001$ ) (Fig. 6).

On the abaxial surfaces between treated and half-treated number of mites was significantly different at $\mathrm{LC}_{30}$ : abamectin $\left(t_{2.167}=2.89 ; P=0.023\right)$, vegetable oil $\left(t_{2.67}=2.42 ; P=0.038\right)$ and EnSpray $99\left(t_{3.17}=3.03 ; P=0.014\right)$ except SYP-9625 and control. At $\mathrm{LC}_{50}$, a significant difference was observed between treated and half-treated surfaces with all mites repelled from treated surfaces (SYP-9625, abamectin and EnSpray 99) (Fig. 7).

In no choice teste (whole plant treated), a significant difference was observed within all treatments (between adaxial and abaxial surfaces): SYP-9625 $\left(t_{-4}=-6.71 ; P=0.001\right)$, Abamectin $\left(t_{-3.17}=-2.53 ; P=0.035\right)$, vegetable oil $\left(t_{-8}=-5.37 ; P=0.003\right)$ and EnSpray $99\left(t_{-7.67}=-3.04 ; P=\right.$ $0.029)$ except control $\left(t_{-1.33}=-1.15 ; P=0.285\right)$ at $\mathrm{LC}_{30}$ doses while all treatments found no difference between adaxial and abaxial surfaces at $\mathrm{LC}_{50}$ doses (Fig. 8).

\section{Correlation analysis}

The correlation between toxicity vs treated and toxicity vs un-treated on both surfaces, either right or left, were found negatively correlated except EnSpray and abamectin (Toxicity vs Treated) at $\mathrm{LC}_{30}$ and $\mathrm{LC}_{50}$, respectively (Supplementary Table 1).

The relationship between toxicity and treated surfaces was positively correlated at $\mathrm{LC}_{30}$ on adaxial (SYP-9625, abamectin, and EnSpray) and abaxial surfaces (abamectin and EnSpray). There was a significant correlation between toxicity and sublethal half-treated abaxial surfaces of SYP-9625, abamectin, and EnSpray 99. There was a positive correlation between toxicity and lethal half-treated adaxial surface for vegetable oil and EnSpray 99. In contrast, on the abaxial surface, only SYP-9625 was found positively correlated (Supplementary Table 2). In a no-choice experiment (the whole plant treated), a positive correlation was observed by treatment with vegetable oil (toxicity vs adaxial) at both concentrations (Supplementary Table 3).

\section{Discussion}

Mites disperse themselves by walking (Sabelis \& Dicke, 1985) to find a suitable site for colonization and feeding (Tixier et al., 2000; Aguilar-Fenollosa et al., 2016; Moerman, 2016; 
236 Mukwevho et al., 2017; Sousa et al., 2019). One major factor for dispersal is environmental 237 contamination, due to pesticide application (Lima et al., 2015; Guedes et al., 2016; Mohammed 238 et al., 2019; Monteiro et al., 2019b). This study aimed to determine whether synthetic chemicals 239 and oils respond similarly to the dispersal and colonization behavior of Panonychus citri. The 240 physio-morphic characteristics of leaf such as leaf surfaces and leaf domatia play an essential 241 role in habitat selection (O’Dowd \& Pemberton, 1994, 1998; Tixier et al., 2000; English-Loeb et 242 al., 2002; Romero \& Benson, 2004). The majority of mites (Tetranychids) prefer to feed and 243 oviposit on the leaves' abaxial surface. In contrast, some phytophagous mites like $P$. citri and 244 Tetranychus urticae are preferred on both surfaces (Azandeme-Hounmalon et al., 2014). This 245 mites distribution from treated surfaces due to chemical cues (Domingos et al., 2010; Melo et al., 246 2011) and maybe their phylogenetical responses (Rollo et al., 1994; Nilsson \& Bengtsson, 2004; 247 Cisak et al., 2012; Buehlmann et al., 2014).

248 In the citrus growing region of South China, SYP-9625 and abamectin are commonly used 249 against different pests, including citrus red mite (Meng et al., 2002; Fang et al., 2013; Huixia et 250 al., 2013; Liao et al., 2016; Dou et al., 2017). SYP-9625 is commonly used against phytophagous 251 mites with minimum hazard to animals (Li et al., 2010; Chai et al., 2011; Huixia et al., 2013; Yu 252 et al., 2016; Liu et al., 2018; Ouyang et al., 2018; Chen et al., 2019). Liu et al. (2018) reported 253 that SYP-9625 gave maximum mortality and dispersed against $P$. cirti in the no-choice test, 254 similar to our results and against Tetranychus citri (Chen et al., 2019). Abamectin showed less 255 repellency than SYP-9625 against $P$. citri (Dou et al., 2017) due to resistance development 256 (NATESC, 2003; Hu et al., 2010; Liao et al., 2016).

257 By contrast to synthetic chemicals, plant-based derivatives (such as vegetable oils) are used as 258 alternatives (Flamini, 2003) due to their compatibility with non-target organisms, low toxicity, 259 negligible resistance development, and eco-friendly (Marcic, 2012). Fatty acids that are 260 significant vegetable oil components are active ingredients that increase their toxicity against 261 pests (Baldwin et al., 2009; Sims et al., 2014). Linoleic acid that is an important component of 262 vegetable oil resulted in attractive responses (Rollo et al., 1994; Buehlmann et al., 2014), as $P$. 263 citri found on treated surfaces (at $\mathrm{LC}_{50}$ ) after 24 hours in this study. The short-chain compound 264 (palmitic acid) in vegetable oil gave equal repellency to synthetic chemicals in previous studies 265 (Mullens et al., 2009; Buehlmann et al., 2014). Vegetable oils gave similar responses to synthetic 266 chemicals with a slow mode of action. They can be used as an alternative against $P$. citri with 267 Ribeiro et al. (2014) endorsement.

268 EnSpray 99 exhibits minimum toxic residues on the treated fruit surfaces by losing their toxicity 269 (Zhuang et al., 2015). The efficacy of EnSpray 99 has been reported against different pests, 270 including citrus red mites by many researchers (Wang et al., 2004; Chen \& Zhan, 2007; Tao \& 271 Xiao-fang, 2011; Teifemg et al., 2011; Zhuang et al., 2015). The EnSpray 99 contains paraffinic 272 oil more than 60\%, which was also found on the fruit residues (Ahmad et al., 2018) and 273 effectively used against $P$. citri (Riehl \& Jeppson, 1953; Trammel, 1965). The study shows that 274 EnSpray 99 responded similarly to vegetable oil and synthetic chemicals against the repellency 275 and dispersal of $P$. citri. The recommended concentrations ranging from 0.5 to $1.4 \%$ against $P$. 
276 cirti and eriophyids (Benfatto et al., 2002; Tang et al., 2002) while Wang et al. (2004) used 14.11 $277 \mathrm{mgL}^{-1}\left(\mathrm{LC}_{50}\right)$ against $P$. citri in the laboratory. EnSpray 99 can be used against $P$. citri control 278 strategies by keeping their impact on pest resistance development, environmental contamination, 279 plant growth reduction, and chronic and acute effect on humans (Ahmed \& Fakhruddin, 2018).

280 According to a free-choice bioassay on dispersal, all mites were significantly dispersed towards 281 the un-treated and half-treated surfaces. According to Alves et al. (2005), untreated surfaces were 282 significantly preferred by the $P$. citri at the adult stage for feeding and oviposition. Maximum 283 dispersal from treated to un-treated or half-treated surfaces depended on the concentration of 284 chemicals Iftner \& Hall (1983). The dispersal towards half-treated adaxial surfaces was 285 significantly different from vegetable oil application than others at $\mathrm{LC}_{30}$, as observed by Alves et 286 al. (2018).

287 The comprehensive assessments of these chemicals against $P$. citri need a more detailed study. 288 The surface treated with these chemicals may affect natural enemies efficiency. However, the 289 experiment carried out here did not evaluate the other factors and needed attention to more 290 applied work.

\section{Conclusions}

292 In conclusion, $P$. citri preferred site adaxial surfaces of citrus leaves for feeding and colonization 293 which were the best sprayed sites for acaricides. However, spraying more times and unequally, 294 P. citri would disperse more quickly. Vegetable oil and EnSpray 99 were the least affecting the 295 colonization depending on mite release point and SYP-9625 gave maximum repellency with a 296 higher number of missing or dead mites recorded.

\section{Acknowledgments}

298 This work was funded by National Key R\&D Program of China (2017YFD0202000), Dean fund 299 of Guangdong Academy of Agricultural Sciences (BZ201906), China Postdoctoral Research 300 Foundation supported the research (229807), China Litchi and Longan Research System 301 Foundation (CARS-32-12), and Discipline team-building projects of Guangdong Academy of

302 Agricultural Sciences in the 13th Five-year period were the support funding agencies for this 303 research work.

\section{References}

305 Aguilar-Fenollosa E, Rey-Caballero J, Blasco JM, Segarra-Moragues JG, Hurtado MA, Jaques JA. 2016. Patterns of ambulatory dispersal in Tetranychus urticae can be associated with host plant specialization. Experimental and Applied Acarology 68:1-20.

Ahmad MM, Wani AA, Sofi M, Ara I. 2018. Mineral oil residues in soil and apple under temperate conditions of Kashmir, India. Environmental Monitoring and Assessment 190. DOI: $10.1007 / \mathrm{s} 10661-018-6586-6$.

Ahmed F, Fakhruddin ANM. 2018. A review on environmental contamination of petroleum hydrocarbons and its biodegradation. International journal of environmental sciences and natural resources 11:1-7. DOI: 10.19080/IJESNR.2018.11.555811.

AliNiazee MT, Cranham JE. 1980. Effect of four synthetic pyrethroids on a predatory mite, Typhlodromus pyri. on apples in southeast England. Environ Entomol 9:436-439.

Alves EB, Casarin NF, Omoto C. 2005. Mecanismos de dispersão de Brevipalpus phoenicis (Geijskes) (Acari: Tenuipalpidae) em pomares de citros. Neotropical Entomology 34:89-96. 
DOI: $10.1590 / \mathrm{S} 1519-566 \mathrm{X} 2005000100013$.

Alves EB, Casarin NFB, Omoto C. 2018. Lethal and sublethal effects of pesticides used in Brazilian citrus groves on Panonychus citri (Acari: Tetranychidae). Arquivos do Instituto Biológico 85.

Azandeme-Hounmalon GY, Fellous S, Kreiter S, Fiaboe KKM, Subramanian S, Kungu M, Martin T. 2014. Dispersal behavior of Tetranychus evansi and T. urticae on tomato at several spatial scales and densities: implications for integrated pest management. Plos One 9.

Baldwin RW, Koehler PG, Pereira RM. 2009. Toxicity of fatty acid salts to German and American cockroaches. Indian Journal of Natural Products and Resources 8:1384-1388. DOI: $10.1093 /$ jee/101.4.1384.

Begon M, Towsend CR, Harper JL. 2007. Organismos. In: Begon M, Towsend CR, Harper JL (eds. . eds. Ecologia: de indivíduos a ecossistemas. Artmed, Porto Alegre, RS., 162-185.

Bell JR, Bohan D a, Shaw EM, Weyman GS. 2005. Ballooning dispersal using silk: world fauna, phylogenies, genetics and models. Bulletin of entomological research 95:69-114. DOI: 10.1079/BER2004350.

Benfatto D, Giudice V Lo, Conti F, Tumminelli R. 2002. Spray oil evolution in Italian citrus groves. In: Beattie GA., Watson DM, Stevens ML, Rae DJ, Spooner-Hart RN eds. Spray oils beyond 2000: sustainable pest and disease management. University of Western Sydney, Sydney, Australia, 419.

Bergman CM, Schaefer JA, Luttich SN. 2000. Caribou movement as a correlated random walk. Oecologia 123:364-374.

Biondi A, Zappalà L, Stark JD, Desneux N. 2013. Do biopesticides affect the demographic traits of a parasitoid wasp and its biocontrol services through sublethal effects? PLoS One 8:e76548.

Bowler DE, Benton TG. 2005. Causes and consequences of animal dispersal strategies: relating individual behaviour to spatial dynamics. Biological Reviews 80:205-225.

Buehlmann C, Graham P, Hansson BS, Knaden M. 2014. Desert ants locate food by combining high sensitivity to food odors with extensive crosswind runs. Current Biology 24:960-964. DOI: 10.1016/j.cub.2014.02.056.

Chai B, Liu C, Li H, Zhang H, Liu S, Huang G, Chang J. 2011. The discovery of SYP-10913 and SYP-11277: novel strobilurin acaricides. Pest Manag Sci 67:1141-1146.

Chen Y, Dai G. 2015. Acaricidal, repellent, and oviposition-deterrent activities of 2, 4-di-tertbutylphenol and ethyl oleate against the carmine spider mite Tetranychus cinnabarinus. Journal of pest science 88:645-655.

Chen JC, Gong YJ, Shi P, Wang ZH, Cao LJ, Wang P, Wei SJ. 2019. Field-evolved resistance and cross-resistance of the two-spotted spider mite, Tetranychus urticae, to bifenazate, cyenopyrafen and SYP-9625. Experimental and Applied Acarology 77:545-554. DOI: 10.1007/s10493-019-00359-3.

Chen Z, Ran C, Zhang L, Dou W, Wang J. 2009. Susceptibility and esterase activity in citrus red mite Panonychus citri (McGregor) (Acari: Tetranychidae) after selection with phoxim. International Journal of Acarology 35:33-40. DOI: 10.1080/01647950802655293.

Chen Z, Zhan H. 2007. Effects of 99\% EnSpray EC on controlling leaf folder (Cnaphalocrocis medinalis G. ), strip borer (Chilo suppressalis W.) and planthopper in rice CHEN. Guangxi Agricultural Sciences:415-417.

Cisak E, Wójcik-Fatla A, Zajac V, Dutkiewicz J. 2012. Repellents and acaricides as personal 
364

365

366

367

368

369

370

371

372

373

374

375

376

377

378

379

380

381

382

383

384

385

386

387

388

389

390

391

392

393

394

395

396

397

398

399

400

401

402

403

404

405

406

407

408

409

protection measures in the prevention of tick-borne diseases. Annals of Agricultural and Environmental Medicine 19:625-630.

Clobert J, Danchin E, Dhondt AA, Nichols JD. 2001. Dispersal. Oxford: Oxford Universtity Press.

Clobert J, Le Galliard J, Cote J, Meylan S, Massot M. 2009. Informed dispersal, heterogeneity in animal dispersal syndromes and the dynamics of spatially structured populations. Ecology letters 12:197-209.

Cordeiro GEM, Corre AS, Guedes RNC. 2014. Insecticide-Mediated shift in ecological dominance between two competing species of grain beetles. 9:1-9. DOI:

10.1371/journal.pone.0100990.

Desneux N, Decourtye A, Delpuech J-M. 2007. The sublethal effects of pesticides on beneficial arthropods. Annu. Rev. Entomol. 52:81-106.

Dittrich V, Cranham J, Jepson L, Helle W. 1980. Revised method for spider mites and their eggs (eg Tetranychus spp. and Panonychus ulmi Koch), FAO method no. 10a. FAO Plant Prod Prot Pap 21:49-53.

Domingos CA, Melo JWDS, Gondim MGC, de Moraes GJ, Hanna R, Lawson-Balagbo LM, Schausberger P. 2010. Diet-dependent life history, feeding preference and thermal requirements of the predatory mite Neoseiulus baraki (Acari: Phytoseiidae). Experimental and Applied Acarology 50:201-215. DOI: 10.1007/s10493-009-9308-5.

Dou W, Xia W-K, Niu J-Z, Wang J-J. 2017. Abamectin treatment affects glutamate decarboxylase expression and induces higher GABA levels in the citrus red mite, Panonychus citri. Experimental and Applied Acarology 72:229-244.

Dunning Jr JB, Stewart DJ, Danielson BJ, Noon BR, Root TL, Lamberson RH, Stevens EE. 1995. Spatially explicit population models: current forms and future uses. Ecological Applications 5:3-11.

Edwards PM. 2002. Origin 7.0: scientific graphing and data analysis software. Journal of chemical information and computer sciences 42:1270-1271.

English-Loeb G, Norton AP, Walker MA. 2002. Behavioral and population consequences of acarodomatia in grapes on phytoseiid mites (Mesostigmata) and implications for plant breeding. Entomologia Experimentalis et Applicata 104:307-319.

Evans GO. 1992. Principles of acarology.

Fadamiro HY, Akotsen-Mensah C, Xiao Y, Anikwe J. 2013. Field evaluation of predacious mites (Acari: Phytoseiidae) for biological control of citrus red mite, Panonychus citri (Trombidiformes: Tetranychidae). Florida Entomologist:80-91.

Faez R, Fathipour Y, Ahadiyat A, Shojaei M. 2018a. How Quantitative and Qualitative Traits of Thomson Navel Orange Affected by Citrus Red Mite, Panonychus citri. Journal of Agricultural Science and Technology 20:1431-1442.

Faez R, Shojaii M, Fathipour Y, Ahadiyat A. 2018b. Effect of initial infestation on population fluctuation and spatial distribution of Panonychus citri (Acari: Tetranychidae) on Thomson navel orange in Ghaemshahr, Iran. Persian Journal of Acarology 7.

Fang X, Ouyang G, Lu H, Guo M, Meng X, Liu H. 2013. The effects of different control measures on Panonychus citri and arthropod enemies in citrus orchards. Chinese Journal of Applied Entomology 50:413-420.

Fernández-Caldas E, Puerta L, Caraballo L, Lockey RF. 2014. Mite Allergens. In: Allergens and Allergen Immunotherapy. Taylor \& Francis, 181-201.

Flamini G. 2003. Acaricides of natural origin, personal experiences and review of literature

Peer) reviewing PDF | (2020:09:52647:2:0:NEW 11 Jan 2021) 
410

411

412

413

414

415

416

417

418

419

420

421

422

423

424

425

426

427

428

429

430

431

432

433

434

435

436

437

438

439

440

441

442

443

444

445

446

447

448

449

450

451

452

453

454

455

(1990-2001). Studies in Natural Products Chemistry 28:381-451. DOI: 10.1016/S15725995(03)80146-1.

Gotoh T, Kubota M. 1997. Population dynamics of the citrus red mite, Panonychus citri (McGregor) (Acari: Tetranychidae) in Japanese pear orchards. Experimental and Applied Acarology 21:343-356. DOI: 10.1023/A:1018467526187.

Gu Q, Chen W, Wang L, Shen J, Zhang J. 2010. Effects of sublethal dosage of abamectin and pyridaben on life table of laboratory populations of Tetranychus turkestani (Acari:

Tetranychidae). Acta Entomologica Sinica 53:876-883.

Guedes RNC, Smagghe G, Stark JD, Desneux N. 2016. Pesticide-induced stress in arthropod pests for optimized integrated pest management programs. Annual review of entomology 61:43-62.

Hanski I. 1998. Metapopulation dynamics. Nature 396:41-49.

Hanski I. 1999. Metapopulation ecology. Oxford University Press.

He HG, Jiang HB, Zhao ZM, Wang JJ. 2011. Effects of a sublethal concentration of avermectin on the development and reproduction of citrus red mite, Panonychus citri (McGregor) (Acari: Tetranychidae). International Journal of Acarology 37:1-9. DOI: 10.1080/01647954.2010.491798.

Hu J, Wang C, Wang J, You Y, Chen F. 2010. Monitoring of resistance to spirodiclofen and five other acaricides in Panonychus citri collected from Chinese citrus orchards. Pest Manag Sci 66:1025-1030. DOI: 10.1002/ps.1978.

Huixia T, Chun R, Hongjun L. 2013. Efficacy Trials of 15\% SYP-11277 Solution on Panonychus citri. Pesticide Science and Administration:25.

Ibrahim Y Bin, Yee TS. 2009. Influence of Sublethal Exposure to Abamectin on the Biological Performance of Neoseiulus longispinosus (Acari: Phytoseiidae). Journal of Economic Entomology 93:1085-1089. DOI: 10.1603/0022-0493-93.4.1085.

Iftner DC, Hall FR. 1983. Effects of Fenvalerate and Permethrin on Tetranychus urticae Koch (Acari: Tetranychidae) dispersal behavior. Environmental Entomology 12:1782-1786. DOI: 10.1093/ee/12.6.1782.

Ims RA, Hjermann DØ. 2001. Condition-dependent dispersal. In: Dispersal. Oxford: Oxford University Press, 203-216.

Ismail MSM, Ghallab M, Soliman MFM, AboGhalia AH. 2011. Acaricidal activities of some essential and fixed oils on the two-spotted spider mite, Tetranychus urticae. Egyptian Academic Journal of Biological Sciences, B. Zoology 3:41-48. DOI: 10.21608/eajbsz.2011.14314.

Isman MB. 2008. Botanical insecticides: for richer, for poorer. Pest Management Science: formerly Pesticide Science 64:8-11.

Karmakar S. 2019. A study on different biochemical components of papaya (Carica papaya) leaves consequent upon feeding of citrus red mite (Panonychus citri). In: Biotechnology and Biological Sciences: Proceedings of the 3rd International Conference of Biotechnology and Biological Sciences (BIOSPECTRUM 2019), August 8-10, 2019, Kolkata, India. CRC Press, 69.

Kasap İ. 2009. The biology and fecundity of the citrus red mite Panonychus citri (McGregor)(Acari: Tetranychidae) at different temperatures under laboratory conditions. Turkish Journal of Agriculture and Forestry 33:593-600.

Korhayli S, Barbar Z, Aslan L. 2018. Population Dynamics of the Phytophagous Mites' Predators in Lemon Orchards in Lattakia Governorate, Syria. Arab Journal Of Plant 
456

457

458

459

460

461

462

463

464

465

466

467

468

469

470

471

472

473

474

475

476

477

478

479

480

481

482

483

484

485

486

487

488

489

490

491

492

493

494

495

496

497

498

499

500

501

Protection 36:8-13. DOI: 10.22268/ajpp-036.1.008013.

Koulbanis C, N'guyen QL, Zabotto A, Plot J, Koulbanis IC, Guyen LNQ, Zabotto A, Plot J. 1984. Mixture of vegetable oils based on jojoba oil and cosmetic compositions comprising the mixture.

Kranz J, Schmutterer H, Koch W. 1978. Diseases, pests, and weeds in tropical crops. Soil Science 125:272.

Kumral NA, Cobanoglu S, Yalcin C. 2010. Acaricidal, repellent and oviposition deterrent activities of Datura stramonium L. against adult Tetranychus urticae (Koch). Journal of Pest Science 83:173-180. DOI: 10.1007/s10340-009-0284-7.

Li Y, Liu C, Tian J, Zhou Y, Zhang H, Song Y. 2010. Research of novel 2-acyl cyanoacetic acid derivative SYP-10898. Chinese Journal of Pesticide Science:12.

Liao C-Y, Xia W-K, Feng Y-C, Li G, Liu H, Dou W, Wang J-J. 2016. Characterization and functional analysis of a novel glutathione $\mathrm{S}$-transferase gene potentially associated with the abamectin resistance in Panonychus citri (McGregor). Pesticide biochemistry and physiology 132:72-80.

Lima DB, Melo JWS, Gondim MGC, Guedes RNC, Oliveira JEM, Pallini A. 2015. Acaricideimpaired functional predation response of the phytoseiid mite Neoseiulus baraki to the coconut mite Aceria guerreronis. Ecotoxicology. DOI: 10.1007/s10646-015-1459-z.

Lima DB, Melo JWS, Guedes RNC, Siqueira HAA, Pallini A, Gondim MGC. 2013. Survival and behavioural response to acaricides of the coconut mite predator Neoseiulus baraki. Experimental and Applied Acarology 60:381-393. DOI: 10.1007/s10493-012-9644-8.

Liu S-W, Song Y, Zhang J, Eng C, Ban L, Li B. 2018. Control Effects of SYP - 962530 \% SC Against Different Mite Targets in Field. Modern Agrochemicals 17:18-21.

Liu Z, Xu C, Beattie GA, Zhang X, Cen Y. 2019. Influence of different fertilizer types on life table parameters of citrus red mite, Panonychus citri (Acari: Tetranychidae). Systematic and Applied Acarology 24:2209-2218.

Marcic D. 2012. Acaricides in modern management of plant-feeding mites. Journal of Pest Science 85:395-408. DOI: 10.1007/s10340-012-0442-1.

Melo JWS, Lima DB, Pallini A, Oliveira JEM, Gondim MGC. 2011. Olfactory response of predatory mites to vegetative and reproductive parts of coconut palm infested by Aceria guerreronis. Experimental and Applied Acarology 55:191-202.

Melo JWS, Lima DB, Sabelis MW, Pallini A, Gondim MGC. 2014. Behaviour of coconut mites preceding take-off to passive aerial dispersal. Experimental and Applied Acarology 64:429443.

Meng H, Wang K, Jiang X, Yi M. 2002. Studies on resistance selection by abamectin and fenpropathrin and activity change of detoxicant enzymes in Panonychus citri. Acta Entomologica Sinica 45:58-62.

Minitab. 2016. Minitab statistical software, ver. 17.3. 1.

Moerman F. 2016. Eco-evolutionary responses along an experimental dispersal front, using Tetranychus urticae as a model species.

Mohammed AAAH, Desneux N, Monticelli LS, Fan Y, Shi X, Guedes RNC, Gao X. 2019. Potential for insecticide-mediated shift in ecological dominance between two competing aphid species. Chemosphere 226:651-658.

Monteiro VB, França G V, Gondim MGC, Lima DB, Melo JWS. 2019a. Walking dispersal by Neoseiulus baraki (Acari: Phytoseiidae) on coconut plants. Systematic and Applied Acarology 24:1337-1342.

Peer) reviewing PDF | (2020:09:52647:2:0:NEW 11 Jan 2021) 
502

503

504

505

506

507

508

509

510

511

512

513

514

515

516

517

518

519

520

521

522

523

524

525

526

527

528

529

530

531

532

533

534

535

536

537

538

539

540

541

542

543

544

545

546

547

Monteiro VB, Lima DB, Melo JWS, Guedes RNC, Gondim MGC. 2019b. Acaricide-Mediated Colonization of Mite-Infested Coconuts by the Predatory Phytoseiid Neoseiulus baraki (Acari: Phytoseiidae). Journal of Economic Entomology 112:213-218. DOI: 10.1093/jee/toy291.

Motulsky HJ. 2007. Prism 5 statistics guide, 2007. GraphPad Software 31:39-42.

Mukwevho L, Olckers T, Simelane DO. 2017. Establishment, dispersal and impact of the flowergalling mite Aceria lantanae (Acari: Trombidiformes: Eriophyidae) on Lantana camara (Verbenaceae) in South Africa. Biological Control 107:33-40.

Mullens BA, Reifenrath WG, Butler SM. 2009. Laboratory trials of fatty acids as repellents or antifeedants against houseflies, horn flies and stable flies (Diptera: Muscidae). Pest Management Science 65:1360-1366. DOI: 10.1002/ps.1823.

NATESC. 2003. Monitoring results of pesticide resistance of crop pests of national significance. Pesticde Express 331:23-24.

Nauen R. 2005. Spirodiclofen: Mode of Action and Resistance Risk Assessment in Tetranychid Pest Mites. Journal of Pesticide Science 30:272-274. DOI: 10.1584/jpestics.30.272.

Nilsson E, Bengtsson G. 2004. Endogenous free fatty acids repel and attract collembola. Journal of Chemical Ecology 30:1431-1443. DOI: 10.1023/B:JOEC.0000037749.75695.c5.

O’Dowd DJ, Pemberton RW. 1994. Leaf domatia in Korean plants: floristics, frequency, and biogeography. Vegetatio 114:137-148.

O’Dowd DJ, Pemberton RW. 1998. Leaf domatia and foliar mite abundance in broadleaf deciduous forest of north Asia. American Journal of Botany 85:70-78.

Oliveira NNFCFC, Galvão AS, Amaral EA, Santos AWOO, Sena-Filho JG, Oliveira EE, Teodoro A V., Galvao AS, Amaral EA, Santos AWOO, Sena-Filho JG, Oliveira EE, Teodoro A V. 2017. Toxicity of vegetable oils to the coconut mite Aceria guerreronis and selectivity against the predator Neoseiulus baraki. Experimental and Applied Acarology 72:23-34. DOI: 10.1007/s10493-017-0134-x.

Ouyang J, Tian Y, Jiang C, Yang Q, Wang H, Li Q. 2018. Laboratory assays on the effects of a novel acaricide, SYP-9625 on Tetranychus cinnabarinus (Boisduval) and its natural enemy, Neoseiulus californicus (McGregor). Plos One 13:e0199269.

Perotti MA, Braig HR. 2009. Phoretic mites associated with animal and human decomposition. Experimental and Applied Acarology 49:85-124. DOI: 10.1007/s10493-009-9280-0.

Pralavorio M, Fournier D, Millot P. 1989. Migratory activity of mites: evidence of a circadian rhythm. Entomophaga 34:129-134.

Riehl LA, Jeppson LR. 1953. Narrow-Cut Petroleum Fractions of Naphthenic and Paraffinic Composition for Control of Citrus Red Mite and Citrus Bud Mite1. Journal of Economic Entomology 46:1014-1020. DOI: 10.1093/jee/46.6.1014.

Rollo CD, Czyzewska E, Borden JH. 1994. Fatty Acid Necromones for Cockroaches. Naturwissenschaften 81:409-410. DOI: 10.1007/s001140050095.

Romero GQ, Benson WW. 2004. Leaf domatia mediate mutualism between mites and a tropical tree. Oecologia 140:609-616.

Ronce O. 2007. How does it feel to be like a rolling stone? Ten questions about dispersal evolution. Annu. Rev. Ecol. Evol. Syst. 38:231-253.

Sabelis MW, Afman BP. 1994. Synomone-induced suppression of take-off in the phytoseiid mite Phytoseiulus persimilis Athias-Henriot. Experimental \& applied acarology 18:711-721.

Sabelis MW, Dicke M. 1985. Long range dispersal and searching behaviour. In: Spider mites and their control. Elsevier, 141-160.

Peer) reviewing PDF | (2020:09:52647:2:0:NEW 11 Jan 2021) 
548

549

550

551

552

553

554

555

556

557

558

559

560

561

562

563

564

565

566

567

568

569

570

571

572

573

574

575

576

577

578

579

580

581

582

583

584

585

586

587

588

589

590

591

592

593

Shi WB, Feng MG. 2006. Field efficacy of application of Beauveria bassiana formulation and low rate pyridaben for sustainable control of citrus red mite Panonychus citri (Acari: Tetranychidae) in orchards. Biological Control 39:210-217. DOI: 10.1016/j.biocontrol.2006.06.016.

Sims SR, Balusu RR, Ngumbi EN, Appel AG. 2014. Topical and vapor toxicity of saturated fatty acids to the German cockroach (Dictyoptera: Blattellidae). Journal of Economic Entomology 107:758-763. DOI: 10.1603/ec12515.

Sousa VC, Zélé F, Rodrigues LR, Godinho DP, de la Masselière MC, Magalhães S. 2019. Rapid host-plant adaptation in the herbivorous spider mite Tetranychus urticae occurs at low cost. Current opinion in insect science.

Strong WB, Slone DH, Croft BA. 1999. Hops as a metapopulation landscape for tetranychidphytoseiid interactions: perspectives of intra-and interplant dispersal. Experimental \& applied acarology 23:581-597.

Tak J-H, Isman MB. 2017. Acaricidal and repellent activity of plant essential oil-derived terpenes and the effect of binary mixtures against Tetranychus urticae Koch (Acari: Tetranychidae). Industrial crops and products 108:786-792.

Tang ML, Chen CX, Xie ST, Zhang ZH, Yang QY. 2002. Demonstration of horticultural mineral oil-based citrus IPM programs in China. In: Spray Oils Beyond 2000: Sustainable Pest and Disease Management: Proceedings of a Conference Held from 25 to 29 October 1999 in Sydney, New South Wales, Australia. University of Western Sydney, 372.

Tao L, Xiao-fang Z. 2011. Occurrence Harm and Control of Phenacoccus fraxinus of Lanzhou. Journal of Gansu Forestry Science and Technology 36:43-45.

Teifemg Z, Chunhua S, Quizhu Y, Ailan Z, Haitao H. 2011. Efficacy of three pesticides to control Acaphylla theae and Empoasca vitis (Gothe) in tea field. Journal of Tea 37:11-13.

Tixier M-S, Kreiter S, Auger P. 2000. Colonization of vineyards by phytoseiid mites: their dispersal patterns in the plot and their fate. Experimental \& applied acarology 24:191-211.

Tixier MS, Kreiter S, Auger P, Weber M. 1998. Colonization of Languedoc vineyards by phytoseiid mites (Acari: Phytoseiidae): Influence of wind and crop environment. Experimental and Applied Acarology 22:523-542. DOI: 10.1023/A:1006085723427.

Trammel K. 1965. Properties of petroleum oils in relation to toxicity to citrus red mite eggs. Journal of Economic Entomology 58:595-601. DOI: 10.1093/jee/1.4.277.

Turchen LM, Golin V, Butnariu AR, Guedes RNC, Pereira MJB. 2016. Lethal and sublethal effects of insecticides on the egg parasitoid Telenomus podisi (Hymenoptera: Platygastridae). Journal of economic entomology 109:84-92.

Turchin P. 1998. Quantitative analysis of movement. Sinauer assoc. Sunderland (mass.).

Wang Q, Gu X, Bei Y. 2004. Activities of EnSpray, a petroleum spray oil, on insect pests and joint actions of its mixtures. Acta Agriculturae Zhajiangensis 16:321-323.

Wang S, Tang X, Wang L, Zhang Y, Wu Q, Xie W. 1971. Effects of sublethal concentrations of bifenthrin on the two-spotted spider mite, Tetranychus urticae (Acari: Tetranychidae). Systematic and Applied Acarology 4:481-490.

Weinberg SL, Abramowitz SK. 2016. Statistics using IBM SPSS: An integrative approach. Cambridge university press.

Xue Y, Andrew G, Beattie C, Meats A, Spooner-Hart R, Herron GA. 2009a. Impact of nC24 agricultural mineral oil deposits on the searching efficiency and predation rate of the predatory mite Phytoseiulus persimilis Athias-Henriot (Acari: Phytoseiidae). Australian Journal of Entomology 48:258-264. DOI: 10.1111/j.1440-6055.2009.00714.x.

Peer) reviewing PDF | (2020:09:52647:2:0:NEW 11 Jan 2021) 
594 Xue Y, Meats A, Beattie GAC, Spooner-Hart R, Herron GA. 2009b. The influence of sublethal

595

596

597

598

599

600

601

602

603

604

605

606

607

608

609

610

611 deposits of agricultural mineral oil on the functional and numerical responses of Phytoseiulus persimilis (Acari: Phytoseiidae) to its prey, Tetranychus urticae (Acari: Tetranychidae). Experimental and Applied Acarology 48:291-302. DOI: 10.1007/s10493009-9242-6.

Yu H, Cheng Y, Xu M, Song Y, Luo Y, Li B. 2016. Synthesis, acaricidal activity and structure-activity relationships of pyrazolyl acrylonitrile derivatives. Journal of Agricultural and Food Chemistry 51.

Yuan M-L, Wei D-D, Zhang K, Gao Y-Z, Liu Y-H, Wang B-J, Wang J-J. 2010. Genetic diversity and population structure of Panonychus citri (Acari: Tetranychidae), in China based on mitochondrial COI gene sequences. Journal of Economic Entomology 103:2204 2213. DOI: $10.1603 /$ ec09392.

Zhuang QG, Wang LH, Li MZ, Hou TP, Xie Y. 2015. “EnSpray 99” mineral oils for white peach scale, Pseudaulacaspis pentagona and phytotoxicity to "Hongyang" kiwifruit. Acta Horticulturae 1096:363-370. DOI: 10.17660/ActaHortic.2015.1096.42.

Zwick RW, Field GJ. 1987. Field and laboratory evaluations of fenvalcrate against several insect and mite pests of apple and pear in Oregon. Journal of economic entomology 71:793-796. 


\section{Table 1 (on next page)}

Toxicity of Panonychus citri (\% mortality \pm SE) 24 hours within nine experiment combinations.

Capital letters indicate the differences among the $\mathrm{LC}_{30}$ of treatments with control and lowercase indicates differences among the $\mathrm{LC}_{50}$ of treatments with a control. Different letters in the same column are significantly different at the Tukey test $(\alpha=0.05)$. 
1 Table 1: Toxicity of Panonychus citri (\% mortality \pm SE) 24 hours within nine experiment combinations. Capital letters indicate the 2 differences among the $\mathrm{LC}_{30}$ of treatments with control and lowercase indicates differences among the $\mathrm{LC}_{50}$ of treatments with a

\begin{tabular}{|c|c|c|c|c|c|c|c|c|c|c|}
\hline \multirow{2}{*}{ Treatment } & Concentrations & \multicolumn{9}{|c|}{ Experiments } \\
\hline & $(\%)$ & 1 & 2 & 3 & 4 & 5 & 6 & 7 & 8 & 9 \\
\hline \multirow{2}{*}{ SYP-9625 } & $\mathrm{LC}_{30}$ & $10 \pm 0 \mathrm{~A}$ & $0 \pm 0 \mathrm{~B}$ & $8.889 \pm 1.11 \mathrm{~A}$ & $5.556 \pm 1.11 \mathrm{~A}$ & $6.667 \pm 0 \mathrm{~A}$ & $5.556 \pm 2.22 \mathrm{~A}$ & $13.33 \pm 1.925 \mathrm{~A}$ & $6.667 \pm 0 \mathrm{~A}$ & $35.556 \pm 5.5$ \\
\hline & $\mathrm{LC}_{50}$ & $12.223 \pm 2.22 \mathrm{a}$ & $2.22 \pm 1.11 b$ & $12.22 \pm 1.11 \mathrm{a}$ & $13.33 \pm 1.925 \mathrm{a}$ & $8.889 \pm 2.22 \mathrm{a}$ & $7.778 \pm 1.11 \mathrm{a}$ & $17.778 \pm 1.11 \mathrm{a}$ & $7.778 \pm 1.11 \mathrm{a}$ & $41.11 \pm 4$. \\
\hline \multirow{2}{*}{ Abamectin } & $\mathrm{LC}_{30}$ & $2.22 \pm 1.11 \mathrm{BC}$ & $2.22 \pm 1.11 \mathrm{~B}$ & $0 \pm 0 \mathrm{~B}$ & $2.22 \pm 1.11 \mathrm{~B}$ & $7.778 \pm 1.11 \mathrm{~A}$ & $3.33 \pm 0 \mathrm{~A}$ & $10 \pm 0 \mathrm{~A}$ & $3.33 \pm 1.925 \mathrm{~A}$ & $12.22 \pm 1.1$ \\
\hline & $\mathrm{LC}_{50}$ & $6.667 \pm 0 \mathrm{ab}$ & $3.33 \pm 0 \mathrm{~b}$ & $5.556 \pm 1.111 \mathrm{~b}$ & $6.667 \pm 0 \mathrm{abc}$ & $12.22 \pm 2.22 \mathrm{a}$ & $4.44 \pm 1.11 \mathrm{ab}$ & $16.667 \pm 1.925 \mathrm{a}$ & $4.44 \pm 1.11 \mathrm{ab}$ & $22.22 \pm 4.0$ \\
\hline \multirow{2}{*}{ Vegetable oil } & $\mathrm{LC}_{30}$ & $7.778 \pm 1.11 \mathrm{AB}$ & $0 \pm 0 \mathrm{~B}$ & $0 \pm 0 \mathrm{~B}$ & $0 \pm 0 \mathrm{~B}$ & $3.33 \pm 0 \mathrm{~A}$ & $2.22 \pm 2.22 \mathrm{~A}$ & $6.667 \pm 1.925 \mathrm{AB}$ & $1.11 \pm 1.11 \mathrm{~A}$ & $8.889 \pm 1.1$ \\
\hline & $\mathrm{LC}_{50}$ & $13.33 \pm 1.925 \mathrm{a}$ & $2.22 \pm 1.11 \mathrm{~b}$ & $2.222 \pm 1.111 b c$ & $3.33 \pm 1.925 b c$ & $5.556 \pm 1.11 \mathrm{ab}$ & $6.667 \pm 0 \mathrm{a}$ & $12.22 \pm 1.11 \mathrm{a}$ & $5.556 \pm 1.11 \mathrm{ab}$ & $11.11 \pm 1.1$ \\
\hline \multirow{2}{*}{ EnSpray 99} & $\mathrm{LC}_{30}$ & $12.22 \pm 1.11 \mathrm{~A}$ & $7.778 \pm 1.11 \mathrm{~A}$ & $0 \pm 0 \mathrm{~B}$ & $0 \pm 0 \mathrm{~B}$ & $4.444 \pm 1.11 \mathrm{~A}$ & $0 \pm 0 \mathrm{~A}$ & $8.889 \pm 2.22 \mathrm{~A}$ & $4.44 \pm 2.22 \mathrm{~A}$ & $7.778 \pm 1.11$ \\
\hline & $\mathrm{LC}_{50}$ & $12.22 \pm 2.94 \mathrm{a}$ & $8.889 \pm 1.11 \mathrm{a}$ & $0 \pm 0 \mathrm{c}$ & $8.889 \pm 1.11 \mathrm{ab}$ & $7.778 \pm 1.11 \mathrm{a}$ & $6.667 \pm 1.925 \mathrm{a}$ & $13.33 \pm 3.849 \mathrm{a}$ & $5.556 \pm 1.11 \mathrm{ab}$ & $7.778 \pm 1.11$ \\
\hline \multirow{4}{*}{$\begin{array}{l}\text { Statistics } \\
\text { at } \\
d f=4,14\end{array}$} & $\mathrm{LC}_{30}$ & $F=18.08$ & $F=23$ & $F=64$ & $F=12$ & $F=12.17$ & $F=2.05$ & $F=7.69$ & $F=3.33$ & $F=22.7$ \\
\hline & & $P=0.000$ & $P=0.000$ & $P=0.000$ & $P=0.001$ & $P=0.001$ & $P=0.164$ & $P=0.004$ & $P=0.056$ & $P=0.00$ \\
\hline & $\mathrm{LC}_{50}$ & $F=7.50$ & $F=7.50$ & $F=35.50$ & $F=10.60$ & $F=8.35$ & $F=4.88$ & $F=11.97$ & $F=5.83$ & $F=33.1$ \\
\hline & & $P=0.005$ & $P=0.005$ & $P=0.000$ & $P=0.001$ & $P=0.003$ & $P=0.019$ & $P=0.001$ & $P=0.011$ & $P=0.00$ \\
\hline
\end{tabular}

3 control. Different letters in the same column are significantly different at the Tukey test $(\alpha=0.05)$. 


\title{
Figure 1
}

Figure 1. Systematic outline of the experimental layout.

\begin{abstract}
(A) Mites were released on the right adaxial (ADR) surfaces; $B$ ) $A D R$ and $A D L ; C) A B R$ and $A B L ; D$ ) $A D R$ and $A B R ; E) A D L$ and $A B L ; F) A D R$ and $A B L ; G) A B R$ and $A D L ; H)$ for full treated $A D R$ and $A B R$, and for half treated, $A D L$ and $A B L ;$ I) for full treated $A D L$ and $A B L$, and for half treated $A D R$ and $A B R$, and J) whole plant treated.
\end{abstract}

Letters were assigned to leaves surfaces as; adaxial right (ADR), adaxial left (ADL), abaxial right (ABR), and abaxial left $(A B L)$.

Photo credit: Muhammad Asif Qayyoum. 


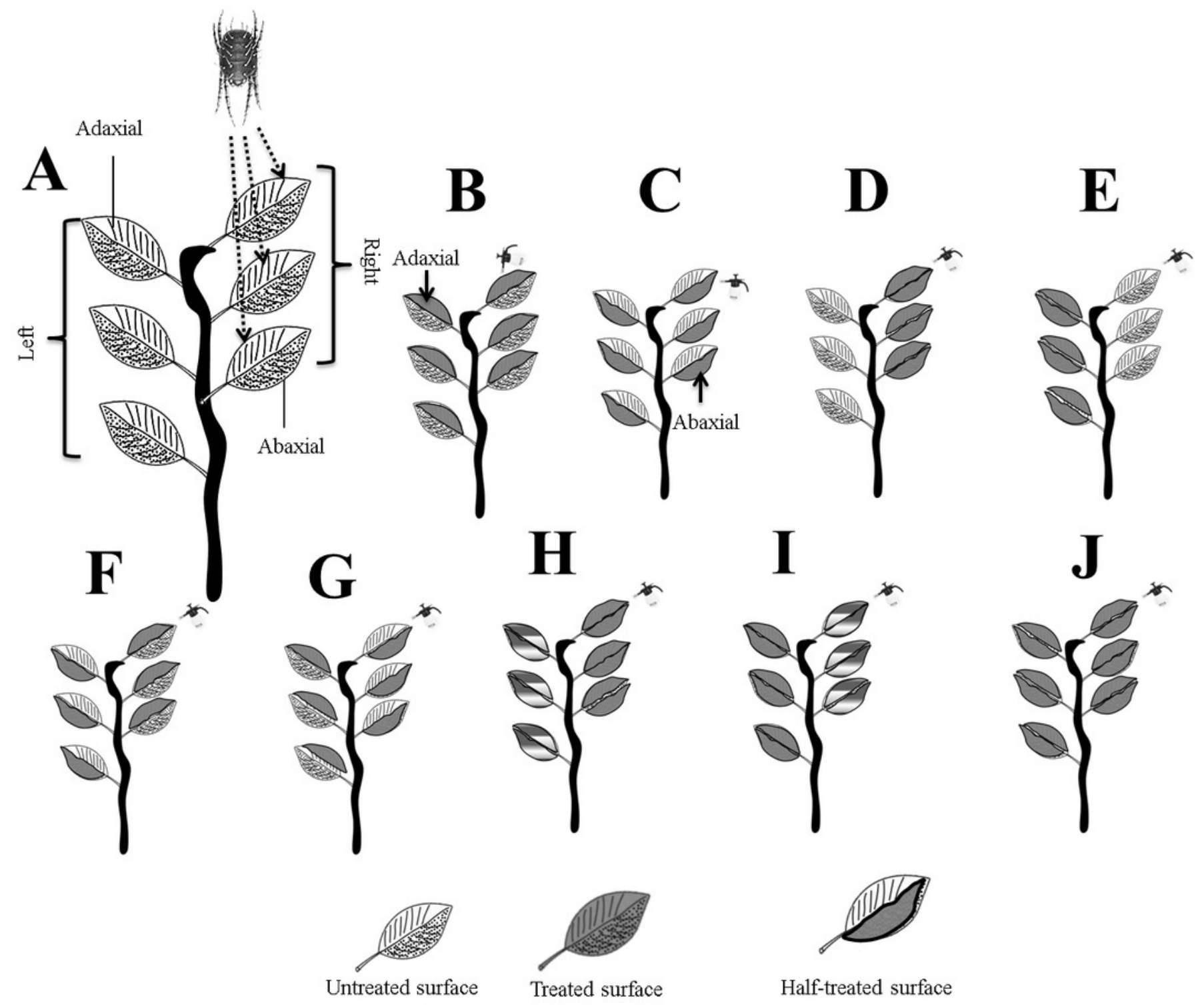




\section{Figure 2}

The number of Panonychus citri (Mean $\pm \mathrm{SE}$ ) re-captured after 24 hours on the adaxial surface of leaves (right side); (A) $\mathrm{LC}_{30}$, (B) $\mathrm{LC}_{50}$.

A significant difference was observed between treatments than control within treated $(d f=$ 4,14; For $\mathrm{LC}_{30}: F=3.37, P=0.018$; for $\mathrm{LC}_{50}: F=28.01, P=0.000$ ) and untreated surfaces (For $\mathrm{LC}_{30}: F=7.41, P=0.000$; for $\mathrm{LC}_{50}: F=4.74, P=0.003$ ). The capital letters indicate differences among the treatments (Treated or Un-Treated); lowercase indicates differences between treated and untreated surfaces, Tukey test $(\alpha=0.05)$. Significant difference "***" and non-significant difference "ns".
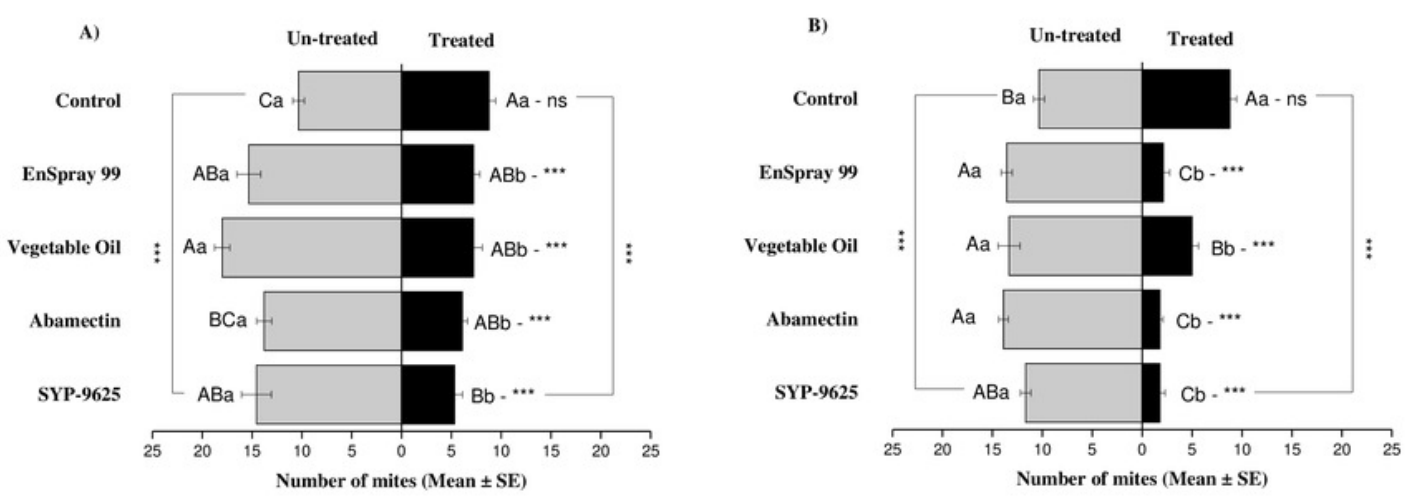
Figure 3

The number of Panonychus citri (Mean $\pm \mathrm{SE}$ ) re-captured after 24 hours on the adaxial surface of leaves (left side); (A) $L C_{30}$, (B) $L C_{50}$.

A significant difference was observed between treatments than control within treated at $\mathrm{LC}_{50}$ $(F=14.67, P=0.000)$. The capital letters indicate differences among the treatments (Treated or Un-Treated); lowercase indicates differences between treated and untreated surfaces, Tukey test $(\alpha=0.05)$. Significant difference "***" and non-significant difference "ns".
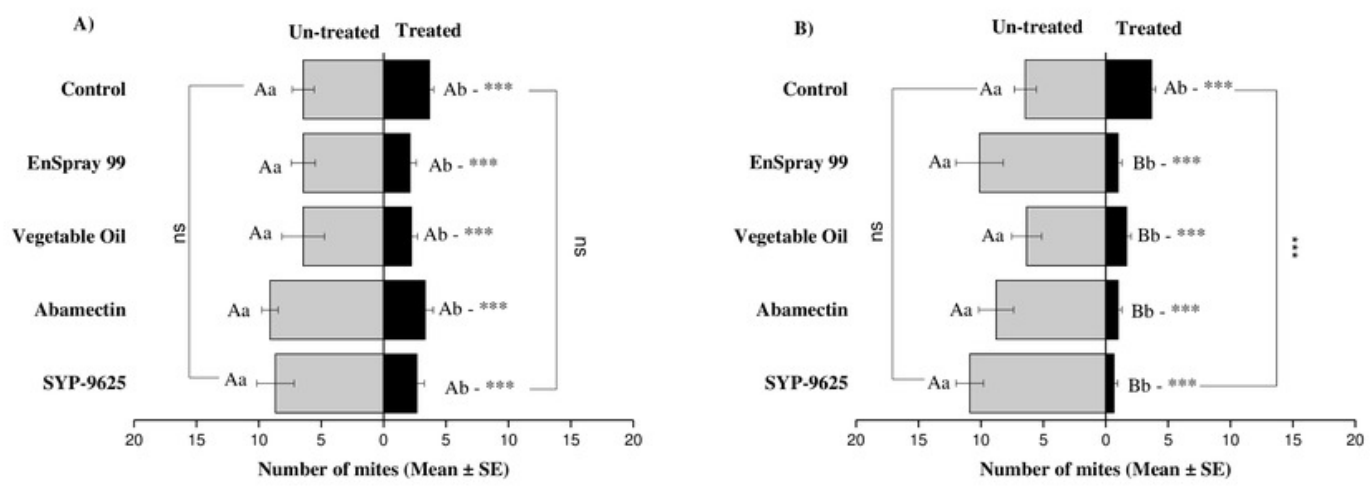
Figure 4

The number of Panonychus citri (Mean $\pm \mathrm{SE}$ ) re-captured after 24 hours on the abaxial surface of leaves (right side); (A) $\mathrm{LC}_{30}$, (B) $\mathrm{LC}_{50}$.

A significant difference was observed between treatments than control at $\mathrm{LC}_{50}$ (For treated: $F$ $=10.86, P=0.000$; for untreated: $F=4.89, P=0.003)$. The capital letters indicate differences among the treatments (Treated or Un-Treated); lowercase indicates differences between treated and untreated surfaces, Tukey test $(\alpha=0.05)$. Significant difference "***" and non-significant difference "ns".
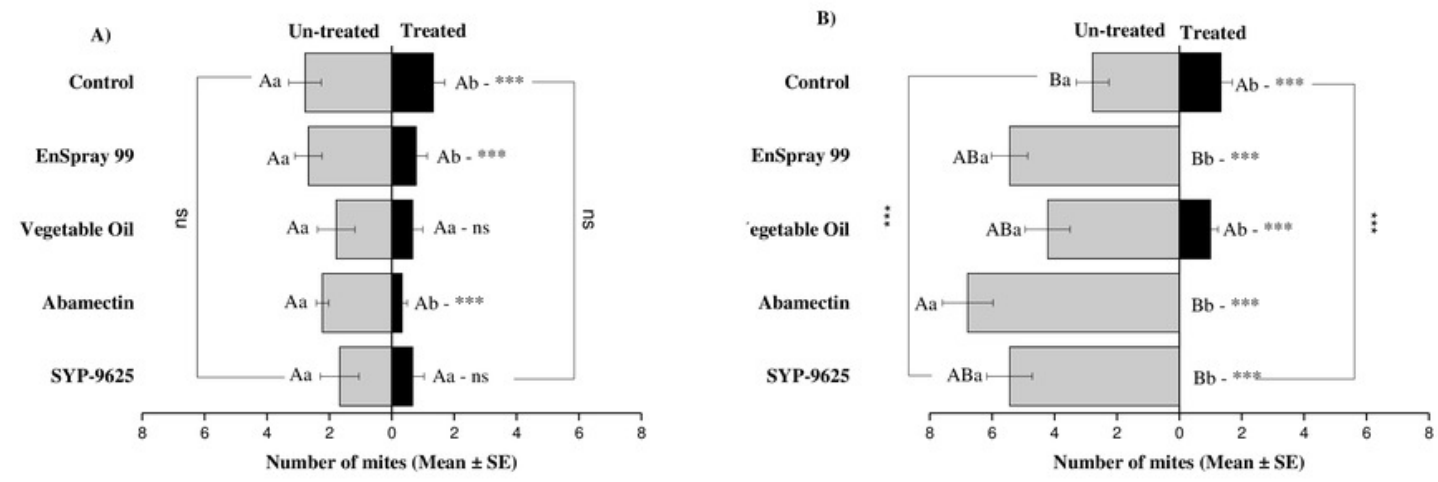


\section{Figure 5}

The number of Panonychus citri (Mean $\pm \mathrm{SE}$ ) re-captured after 24 hours on the abaxial surface of leaves (left side); (A) $\mathrm{LC}_{30}$, (B) $\mathrm{LC}_{50}$.

A significant difference was observed between treatments than control within treated surfaces $\left(d f=4,14 ;\right.$ For $\mathrm{LC}_{30}: F=15.01, P=0.000$; for $\left.\mathrm{LC}_{50}: F=29.78, P=0.000\right)$. The capital letters indicate differences among the treatments (Treated or Un-Treated); lowercase indicates differences between treated and untreated surfaces, Tukey test ( $\alpha=0.05$ ). Significant difference "***" and non-significant difference "ns".
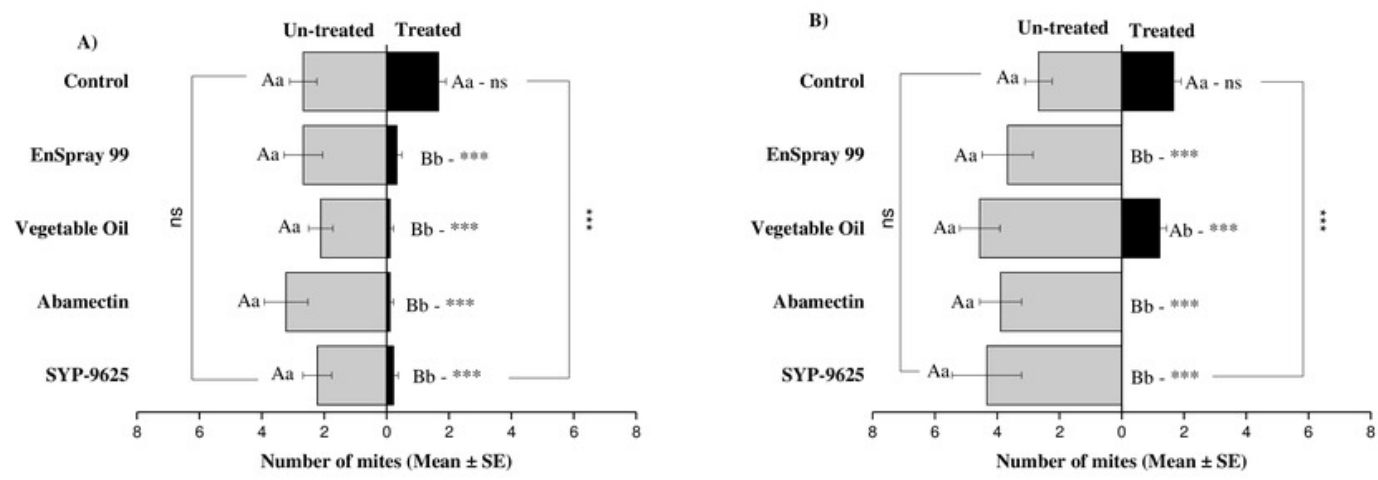


\section{Figure 6}

The number of Panonychus citri (Mean $\pm \mathrm{SE}$ ) re-captured after 24 hours on the adaxial surface of leaves; (A) $L C_{30}$, (B) $L C_{50}$.

A significant difference was observed between treatments than control within treated ( $d f=$ 4,29; at $\mathrm{LC}_{50}: F=8.55, P=0.000$ ). The capital letters indicate differences among the treatments (Treated or Half-Treated); lowercase indicates differences between treated and half-treated surfaces, Tukey test $(\alpha=0.05)$. Significant difference "***" and non-significant difference "ns".
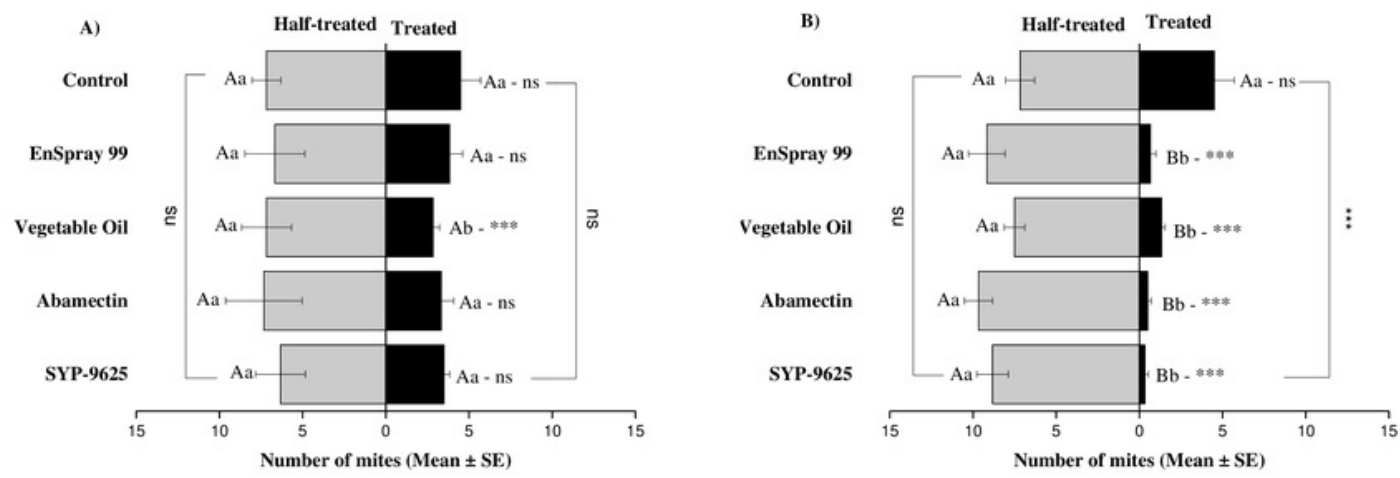
Figure 7

The number of Panonychus citri (Mean $\pm \mathrm{SE}$ ) re-captured after 24 hours on the abaxial surface of leaves; (A) $L C_{30}$, (B) $L C_{50}$.

A significant difference was observed between treatments than control within treated $(d f=$ 4,29; at $\mathrm{LC}_{50}: F=29.61, P=0.000$ ). The capital letters indicate differences among the treatments (Treated or Half-Treated); lowercase indicates differences between treated and half-treated surfaces, Tukey test $(\alpha=0.05)$. Significant difference "***" and non-significant difference "ns".
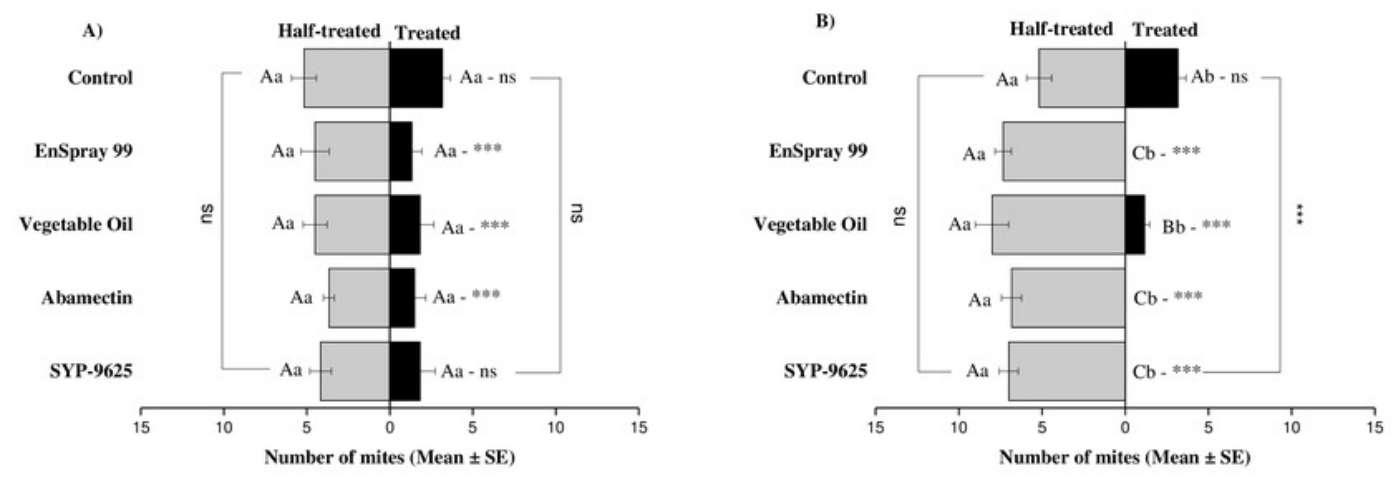


\section{Figure 8}

The number of Panonychus citri (Mean $\pm \mathrm{SE}$ ) re-captured after 24 hours (the whole plant treated) on adaxial and abaxial surfaces. The results of LC30 (A) and LC50 (B) concentrations are presented.

A significant difference was observed between treatments than control within abaxial ( $d f=$ 4,29; at $\left.\mathrm{LC}_{30}: F=8.32, P=0.000\right)$. The capital letters indicate differences among the treatments (Adaxial or Abaxial surface); lowercase indicates differences between adaxial and abaxial surfaces, Tukey test $(\alpha=0.05)$. Significant difference “***" and non-significant difference "ns".
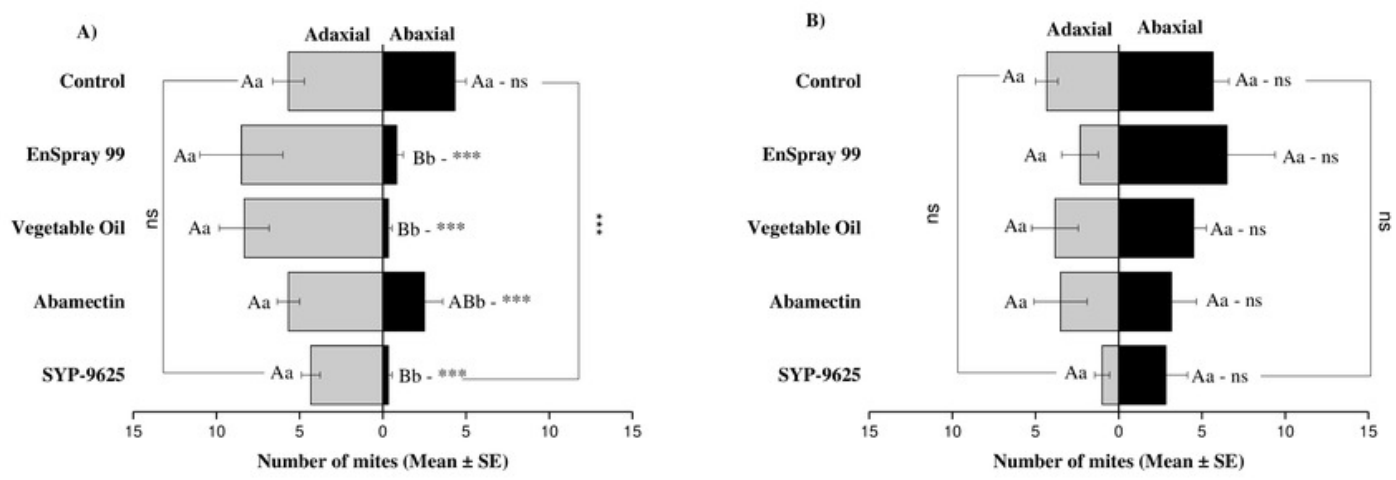